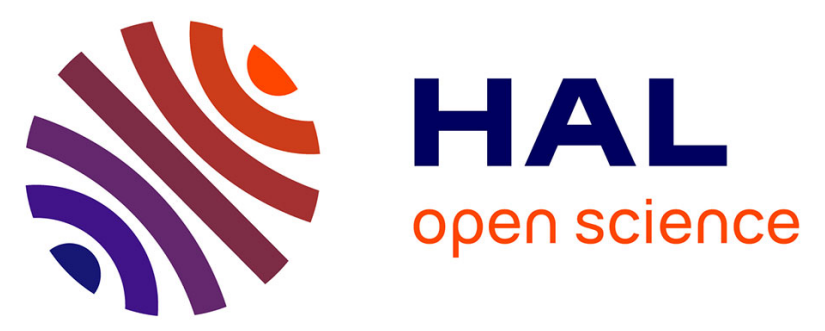

\title{
Contribution of Fair Trade in Sustainable Development
} Md Nazmus Sadekin, Most Asikha Aktar, Md. Mahmudul Alam

\section{To cite this version:}

Md Nazmus Sadekin, Most Asikha Aktar, Md. Mahmudul Alam. Contribution of Fair Trade in Sustainable Development. Walter Leal Filho; Anabela Marisa Azul; Luciana Brandli; Amanda Lange Salvia; Pinar Gökcin Özuyar; Tony Wall. Reduced Inequalities, Springer International Publishing, 2021, Encyclopedia of the UN Sustainable Development Goals, 978-3-319-71060-0. 10.1007/978-3319-71060-0_7-1. hal-03520078

\section{HAL Id: hal-03520078 https://hal.science/hal-03520078}

Submitted on 10 Jan 2022

HAL is a multi-disciplinary open access archive for the deposit and dissemination of scientific research documents, whether they are published or not. The documents may come from teaching and research institutions in France or abroad, or from public or private research centers.
L'archive ouverte pluridisciplinaire HAL, est destinée au dépôt et à la diffusion de documents scientifiques de niveau recherche, publiés ou non, émanant des établissements d'enseignement et de recherche français ou étrangers, des laboratoires publics ou privés. 


\title{
Contribution of Fair Trade in Sustainable Development
}

\author{
Md Nazmus Sadekin \\ Department of Economics \\ Mawlana Bhashani Science and Technology University \\ Santosh, Tangail, Bangladesh \\ Email: sadekin08@gmail.com \\ Most. Asikha Aktar \\ Department of Economics \\ Comilla University \\ Cumilla, Bangladesh \\ Email: asikharita@gmail.com \\ Md. Mahmudul Alam \\ School of Economics, Finance and Banking \\ Universiti Utara Malaysia \\ Sintok, Kedah, Malaysia. \\ Email: rony000@gmail.com \\ * Corresponding Author
}

\section{Citation Reference:}

Sadekin, M.N., Aktar, M.A., \& Alam M.M. (2021). Contribution of Fair Trade in Sustainable Development. In: Walter Leal Filho et al. (eds), Reduced Inequalities: Encyclopedia of the UN Sustainable Development Goals. Springer, Cham. ISBN: 978-3-319-71060-0. (online) https://doi.org/10.1007/978-3-319-71060-0_7-1

This is a pre-publication copy.

The published article is copyrighted by the publisher. 


\title{
Contribution of Fair Trade in Sustainable Development
}

\section{Definition}

\begin{abstract}
"Fair trade is a model for alleviating global poverty. Many companies and markets are investing, impacting developing communities. From building sustainable businesses to providing education, the movement is life-changing for those living in poor communities around the world".
\end{abstract}

\section{-Brandi Gomez}

Fair Trade (FT) is a societal movement that aims to support poor and vulnerable producers in developing nations to attain improved trading conditions with direct link to consumers and excluding mediators in the trading chain (Young and Utting 2005). Therefore FT allows poor producers to be part of a trading organization that make sure a fair and steady price for their products. It also provides them and their systems different level of backing facilities and stimulates sustainable environment.

\section{Introduction}

The concept of Fair Trade (FT), which is being measured as an alternate to traditional trade, and is gradually gaining popularity throughout the world. The concept is related to the movement that seeks to sustain equity at a greater extent in international trade partnerships between developing countries through dialogue, transparency, and respect (Charter, 2009). Therefore, a secondary goal is to move towards FT is to raise consciousness among consumers about the practices of unjust and unfair global trade. So, FT is in excess of just trading as,

$>$ It demonstrates that justice is possible at a greatest level in world trade.

$>$ It focuses on the necessity to change the procedures and practices of traditional trade and presents how an effective trade can placed people first.

$>$ It play a perceptible role to compete in against of poverty, economic crisis, and the climate change.

In addition, it enhances sustainable development (SD) by proposing better environments for trading and, obtaining the freedom and rights of producers in developing countries who are marginalized. Charter (1992) defined SD as "development that meets the needs of the present without compromising the ability of future generations to meet their own needs. The concept is focused on economic development, social development, and environmental protection for future generations". Moreover, there are three fundamental views that ensure movement, as well as contribution of FT to SD (Strong 1997): Firstly, establishing a more coherent association between a group of consumers and producers in the two worlds and a better level of perception between consumers of the need of producers in order to assist their independent improvement. Secondly, traded goods fairly stimulate a pattern of production and consumption that decrease pressure to environment and meet the needs of humankind. Lastly, the establishment of FT practices throughout the relationships between consumer-producer help to decrease environmental degradation and poverty. Although the contribution of FT to SD, is observable, there still have knowledge gap about the status quo in the so called changeover economies. Therefore, this study examines the contribution of FT to SD. The article is initiated 
by referring what "fair trade" is and then elucidates the consent of FT movement and also explains the main principles of FT. In addition it presents the contribution of FT to attain SD.

\section{The Concept of Fair Trade}

The fierce competition for limited resources and the globalization process that began in the second half of the 21 st century has led to controversy over the side effects of these processes, including natural environmental degradation along with increasing income inequality between developed and developing nations. Towards the end of the century, the United Nations and other international organizations warned the world community and commenced campaigned for more SD that would meets the needs of the present generation without sacrificing the ability of future generations to meet their individual needs. Often linked to SD, one of the concepts is FT.

FT is not an organization but a movement or a broad idea that can be drawn back to the 21 st century, even though it has been established in the West over the 40 years before (Brussels Rural Development Briefings 2014).The rising popularity for the last three years is a result of the growing collaboration of businesses on its networks and more explicitly the FT certificate bodies" (Reed 2009). FINE (the name that comes from four FT networking organizations FLO, IFAT, NEWS, and EFTA) has well-defined FT as a dealing corporation, centered on transparency, respect, and dialogue that search for equity at a greater extent in global trading system (Brussels Rural Development Briefings 2014). It rises the issue of uneven distribution of income which prompts the rich more rich and poor more poor. The key goal of FT is to lessen these disparities.

FT in the narrower sense means purchasing goods on terms from the developing countries producers, that terms are more promising than the terms of free market, and selling those goods to the developed countries at the "ethical price premium"(De Pelsmacker et al. 2005; Stefańska and Nestorowicz 2015). The concept of FT in general indicates that it has, in core, two main factors or sights. The first sight is to provide an effective model of international trade that differentiates between consumers and producers involvement. The second and more important sight is to defy accepted view in the practices of business and not just through publicity but as an "instrument to revise the influential economic model" (Renard 2003).

\section{The Consent of Fair Trade Movement}

The starting date of the FT movement is not clear. This steams from the efforts of a number of western-based charities to shift away from the conventional economic paradigm of pursuing the low-priced labor and accessible raw material to a more justifiable business relations. Companies for instance TWIN and Oxfam have created FT trading relationships with groups in the least developed countries by creating contacts, developing their requirements for equipment, tools, and knowledge, and helping them find a market place for their goods (Barratt Brown 1993).

But the instrumental development was in 1946 by a businesswomen Edna Ruth Byler, a spectacular pioneer of a women's sewing group run by the Mennonite Central Committee (MCC) in Puerto Rico. She started to sell a set of craft to her neighbors and friends who are placed in the United States. Her project got acceptance by MCC in 1962 as the Foreign Needlework and Crafts Project, and in 1996, it was retitled as Ten Thousand Villages. Therefore a non-profit organization, SERRV (Sales Exchange for Refugee Rehabilitation and Vocations) was also set up in 1949 by the Church members in United States to establish a trading relations with the South American poor communities. 
The first formal FT shop was developed in the United States in 1958. Subsequently, the FT organization instated to prepare Christmas card and handicraft in 1964 in other developing nations. The FT Original started to purchase goods from the producer of developing countries in 1967, initially they import wood carvings from the slums of Port-au-Prince, Haiti and later developed businesses in Austria, West Germany, Switzerland, and Belgium. Highlighted that "Trade not aid" a new political agenda underlined in 1968 by the developing nations at the second session of the United Nations Conference on Trade and Development (UNCTAD) in New Delhi that emphasized on establishment of an equitable trade relations between countries.

The first World Shop was inaugurated in the Dutch town of Berkeley in 1969 through retailing sugarcane and importing handicrafts. Coffee was accounted as a fair trade product in 1973, initially imported from the Guatemala cooperatives. Therefore to support the fair trade product as such for reaching to a broader audience, the 1980s promised the establishment of labeling organizations for FT. Consequently, in 1988, the Max Havelaar label fashioned in the Netherlands, was termed after a fictitious character who fought in against of government exploitation and harassment of local coffee farmers by the Dutch colonialist in 19th-century Java. The same labelling also followed in other European and North American countries, driving to the formation of the worldwide Fairtrade Labelling Organizations (FLO), initiated in 1997.

The International Federation of Alternative Trade (IFAT; later renamed World Fair Trade Organization, WFTO) was beginning in 1989, along with thirty-eight FT organizations under one rooftop. By the following year, 1990, the European Fair Trade Association (EFTA) was set up formally, which accompanied by eleven FT import organizations in nine countries of Europe. The FLO, IFAT, NEWS (Network of European World Shops), and EFTA together in 1998 launched as an informal working group called FINE (an acronym of the names of the member organizations). FINE was devoted to raise global consciousness about the FT movement by actively campaigning in political spheres and arranging public dealings.

However, The FLO and the WFTO (previously the International Fair Trade Association, IFTA) are currently working as an international FT standard setters to officially state FT organizations around the world. These two standard-carriers in 2009 adopted the "Charter of Fair Trade Principles" (Charter 2009) - an international reference point for FT that provides a general definition and definition of FT policy, and a common view and its core principles. The WFTO adopted ten FT Principles and also forwarded these principles to the participant organizations (WFTO 2008).

\section{The Main Principles of Fair Trade}

Basically FT was the consumer concept who sought to support the people of the least developed nations. The social purpose of FT is to concentrate on small producers (Reed 2009). Initially their products were sold in small charities and in churches so the relationship between suppliers and purchasers were based on trust (Vieira and Aguiar 2009). Behind the concept of FT movement ten key principles as a general understanding of the basic principles of fair trading were demonstrated by the FT International and the general assembly of WFTO (World Fair Trade Organization 2008). These are named as a 'Charter of FT Principles' (Huybrechts 2010). Therefore, the main principles of FT includes: 
Principle 1: Building opportunities for economically deprived producers-

FT builds opportunities for producers who are economically deprived and promotes SD in developing nations by alleviating poverty as well. It involves reducing poverty by selfdetermining producers economically.

Principle 2: Transparency and Accountability-

FT put into practise transparent and fair trading management and trading relationships with trading partners. It involves the producer in making important decisions.

Principle 3: Fair Trading Practices-

It implicates trading fairly with a broad concern for the economic, social, and environmental welfare of producers. Moreover, it works for building the capacity of its group of producers.

Principle 4: Payment of a Fair Price-

Prices ought to be settled mutually and more than cover production cost (that is sustainable). It also means that workers should be paid fairly and for the same work male and female both would receive the same wages. Purchasers should be assisted in pre-financing if needed. Fair price is the most accepted point and important of FT. It ensures satisfactory level of wages for producers on a social basis by paying a mutually agreed fixed price.

Principle 5: Ensuring no Child Labour-

Full time child labour is prohibited. Children must have the chance to study, rest, and play. Children can help work with the family in a way that does not stop them from going to school, resting or playing. This is a specific difficulty in certain countries, although child labour is now very rare in Thailand

Principle 6: Commitment to Non-Discrimination, Gender Equity and Women's Economic Empowerment and Freedom of Association-

Apart from the same pay for the same work, women holds similar human rights and participation in the organization. Although FT works to develop equality in gender in any circumstances, it is clear that it is even more important in certain cases where inequality in gender is very strong. Also Respect the rights of trade union and reject discrimination on the basis of religion, gender, or culture.

Principle 7: Ensuring Good Working Conditions-

Corresponding to the International Labour Organization (ILO) conventions FT make available for producers and staffs a healthy and safe work environment.

Principle 8: Providing Capacity Building-

FT offer producers and staffs to improve their abilities so that they can continue to develop and succeed.

Principle 9: Promoting Fair Trade-

It helps raise awareness of the need for greater justice in global trade by doing business fairly with the poor group of people.

Principle 10: Respect for the Environment-

It includes taking care of the environment by maximising the usage of sustainable energy and raw materials while reducing pollution and waste. FT practices will certainly not be 
environmentally harmful but will help to improve the condition of environment (Cremona and Durán 2012).

Further objective of the FT movement is to lessen risk and improve access to credit, qualifying producers to create long-term investments. The latter is measured to be the key relevance of poverty-alleviation strategies centered on changing risky behaviors as a pre-requisite for poverty reduction.

\section{The Relationship between Fair Trade and Sustainable Development}

The idea of FT perfectly fits with the concept of SD. The concept of SD was introduced in 1987 for the first time by the World Commission on Environment and Development and it was termed as "Development that meets the needs of present generations without compromising the ability of future generations to meet their own needs" (United Nations 1987). Emphasis has been placed on the idea that this means we need to be in the doughnut without exceeding the planets limits to meet human needs. There are limit to the economic footprint that can be taken to manage the planet. And currently we are going beyond that on multiple levels. In the meantime, we are failing to come across basic human needs. The graphic shows us this. We need to ensure that the benefits of our economic activities benefit people more and more because we cannot keep our footprints high and move beyond our planetary boundaries. This means addressing the issue of inequality. The World Bank acknowledges that we cannot achieve zero poverty without tackling inequality. If the value and means of the economic activity go progressively to the richest, it will not be possible to feed the society. Even not possible to support health and education without a more equal allocation of means. And the worldwide nation will face the social and economic uncertainty if inequality rise continuously. Whereas, growing inequality cannot be ignored because it is the very center of justice. All of this inequality means not as much of money for producers across the world. A small portion of the products value are obtained by the workers and farmers. This is falling people in poverty trap and indicates that we cannot achieve the SDGs. Recognizing the problem of inequality and poverty in the least developed world as a problem, it is concluded that all these problem can be reduced through the practices of SD policies including FT and facilitates the FT practices all the way through producer-consumer relationships. This can be attained through the implementation of FT standards including the basic needs of producers who (in order to be certified) will continue to prosper their organizations and improve the conditions of their workers.

In addition to the products labelled, the FLO postulates two groups of producer standards, one for small farmers and, one for planters and factory workers (Boto and La Peccerella 2008). The required standard is strictly linked to the economic, social, and environmental dimensions of SD which are discussed as follows (Fig.1): 


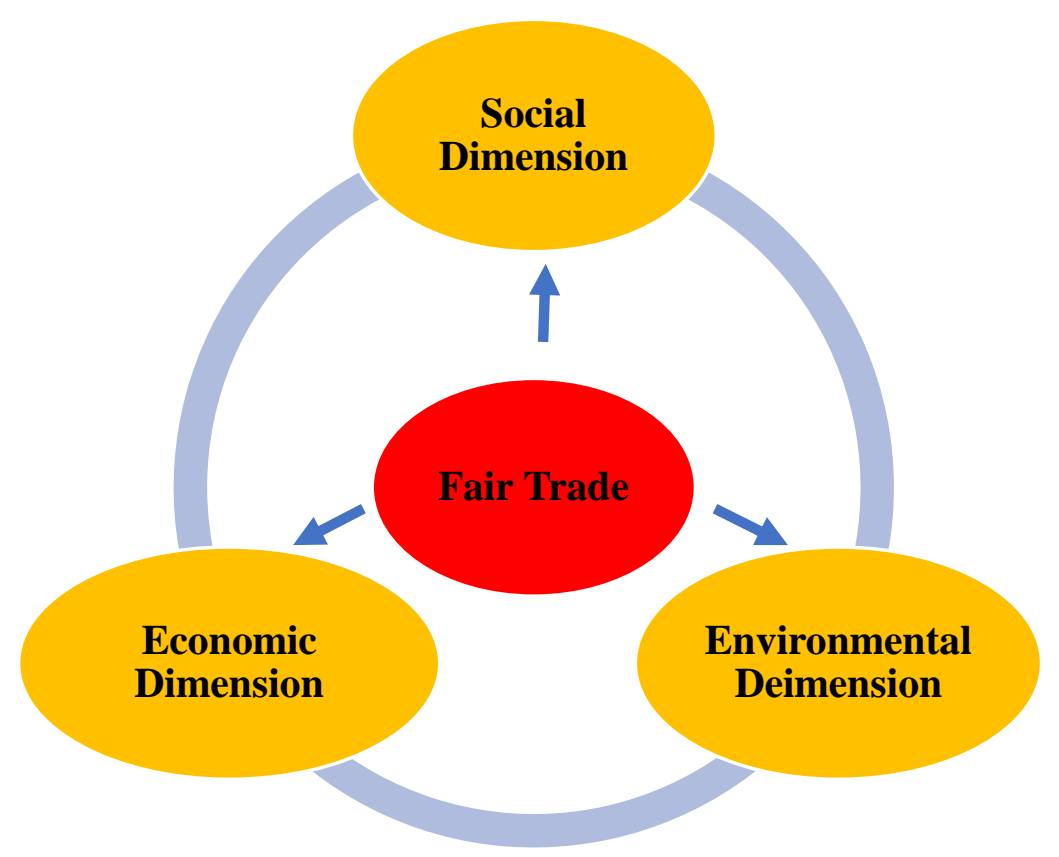

Figure 1: Relationship between Fair trade and Sustainable Development Source: Strong 1997

\section{(i) Social Dimension and Fair Trade}

The Social dimension of sustainable development includes actions and practices that epitomize justice, fairness, standards, and moral responsibilities (Carroll 1991). Sustainable society is attained through respect for the limitations of human and culture. Moreover, restoring the diversity of human culture also assist to support their livelihood system (Ketola 2009b). In developed nations, the social implications of consumption through trade unionism, consumerism, and strict product liability acts are well known. In contrast, there exists lack of these opportunities for developing nations. Developing nations are mainly considered by degrade environment that as well affect their social sustainability. In response to these constraints in developing nations, FT performs main role in maintaining and achieving the necessary goals (Strong 1997).

Fairly traded goods encourage society to use such a production and consumption model that will reduce environmental pressure, and meet the desires of humankind. Fairly traded goods certify sellers in developing nations for a standard manufacturing process, trade facilities and decent working environments for workers. FT helps to create a model of economic development in the least developed countries for the expansion of capital and the usage of natural resources. FT is the best course of action to meet the social needs of a community on the basis of their specific environmental circumstances. FT provides a platform for alleviating poverty and environmental problems where FT and The provision of FT practices play a role in building a consumer-producer relationship (Strong 1997). Another socially relevant issue is the labor standard, which needs to be enforced by a FT organization. Therefore, fair trade FLO require standards for small farmers and hired labour (table 1) as follows:

Table 1: Fair trade FLO standards for small farmers and hired labour

\begin{tabular}{|c|c|}
\hline For small farmers & For hired labour \\
\hline $\begin{array}{l}\text { A non-discriminatory, democratic } \\
\text { organisational structure that enables } \\
\text { farmers to bring a product to the } \\
\text { market }\end{array}$ & $\begin{array}{l}\text { The company involved to bring } \\
\text { social rights and security to its } \\
\text { workers } \\
>\text { Training opportunities }\end{array}$ \\
\hline
\end{tabular}




\begin{tabular}{|c|c|}
\hline $\begin{array}{l}\text { The organisation must be set up in a } \\
\text { transparent way } \\
\text { It must not discriminate against any } \\
\text { particular member or social group }\end{array}$ & $\begin{aligned} & \text { Non-discriminatory employment } \\
& \text { practices }\end{aligned}$ \\
\hline
\end{tabular}

Source: FLO 2014

(i) Economic Dimension and Fair Trade

The economic aspect of SD is closely interrelated to the financial sustainability of the firm and it integrates with the standards of firms (Ketola 2009a).Traditionally, trading organizations are created for economic activities while generating profit is the initial motive for all organizations (Carroll 191). Staying within the limited financial resources, local, regional and global ethical and legal standards assist firms to attain sustainable economy, and to maintain eco-friendly and socio-culturally life (Ketola 2009a). Therefore, FT not only creates wealth but also plays a creative role to achieve economic sustainability by rewarding fairly of all stakeholders with a more equal distribution of wealth (Jacobs 1991). Also, the principle of FT incorporates non-economic standards of equity i.e., ethical aspects, environmental standards, and standard of life into the distribution of profits and trading facilities. Thus the goals of FT differ from conventional economic goals, and are not based on purely financial goals but on fair price (i.e., a FT premium or a FT minimum price), sustainable production costs, sustainable use of natural resources, and rebuilding community profits for health care and education.

\section{(ii) Environmental Dimension and Fair Trade}

The meaning of the Brundtland report was that a FT relationship with the environmental dimension is possible by maintaining "the needs of the present generations without compromising the ability of future generations to meet their own needs". Efforts should be made by organizations to attain environmental sustainability within the ecological limits (Ketola 2009a). The principle of FT combine both the preservation assessment and collaboration with its good working quality and environments. In this context, it deals with the widespread utilisation of mineral and forest resources to improve the quality of life and access to a greater number of consumer products and services by portion of mankind. Ketola (2009a) explained that the use of renewable energy, recyclable or renewable natural resources, and zero emissions such as environmental dimension of SD. As a strategic part of climate change, FT has developed FT climate Standards to support smallholders and rural populations to become more prosperous in the effects of climate change on an international basis (FLO 2015b). The focal points are-

$>$ minimised and protected usage of agrochemical

$>$ safe and Proper waste management

$>$ Maintain fertility of soil and water resources 
$>$ Prohibited the use of heritably modified bacteria

\section{Pursuing Sustainable Development Goals: The Role of Fair Trade}

The milestone for progression of SD and execution of its plans into local life became an Agenda 21, one of the key documents of the 1992 United Nations Conference on Environment and Development (Earth Summit) which held in Rio de Janeiro (Pearcy and Schrock 2014). The document, and its strategic nature includes a set of suggestions and guidelines for how social and economic development can be planned for SD in a $21^{\text {st }}$ century perspective and without compromising the natural environment. The Rio+20 outcome and the agenda 2030 for SD acknowledges international trade as an engine of comprehensive economic growth and poverty reduction, and a significant way to attain the SD Goals (SDGs). Adopting the 2030 Agenda to support the contribution of trade to the achievement of the SD agenda pledges the member states of UN to continue promoting "meaningful" trade liberalization for the following 15 years. In this context, it is expected that international trade as a means of execution will play its role for the success of the SDGs. As such the FT exemplifies the importance of partnership approach to SD, highlighting the notion that the concept of green economics to attain sustainability articulated by green researchers is more based on co-operation than competitive win/lose transaction relationships.

Similarly Carlo Ripa di Meana (1992; Environmental Commissioner for the EC) considers that for attaining SD, the developed countries must be ready to shift the policy of both financing, new technology and equal trade in business transactions with the least developed countries, rather than the current wide-ranging unequal exploitative system. He also believes that economic growth may not be sustained without considering both the environment and the impact on the environment of unconstrained growth in production.

In line with the vision of FT presented by the Charter (2009), the movement toward FT "shares a vision of a world in which fairness and SD are at the heart of trade structures and practices so that everyone, through their work, can maintain a decent and dignified livelihood and develop their full human potential" - specifically in the South supports the concept of SD. The WFTO sets out ten Principles (WFTO 2013) that FT organizations must follow in their day-today operations as discussed before and oversees to ensure that these principles are being implemented. In many attributes, these ten principles of FT relate with the goal of SD (Table 2).

Table 2: fair trade principles correspond with SDG

\begin{tabular}{|ll|l|}
\hline Fair Trade Principles & SDGs \\
\hline $\begin{array}{l}\text { Enable producers and workers to } \\
\text { maintain a sustainable livelihood. }\end{array}$ & $\begin{array}{l}\text { SDG 1: No poverty } \\
\text { SDG 2: Zero hunger }\end{array}$ \\
\hline 2. & $\begin{array}{l}\text { develop the skills and capabilities of } \\
\text { employees or members }\end{array}$ & SDG 3: Quality Education \\
\hline 3. & $\begin{array}{l}\text { Provide opportunities for women to } \\
\text { receive equal pay to men for equivalent } \\
\text { work, and fully participate in decisions } \\
\text { concerning the use of benefits accruing } \\
\text { from production and from Fair Trade } \\
\text { relationships }\end{array}$ & \\
\hline 4. & $\begin{array}{l}\text { Support fair wages, prompt payment, and } \\
\text { safe and empowering working conditions } \\
\text { for all throughout the trading chain. }\end{array}$ & SDG 8: Decent work \\
\hline 5. $\begin{array}{l}\text { Facilitate sustainable and resilient } \\
\text { infrastructure development and support }\end{array}$ & SDG 9:Industry, Innovation, and Infrastructure \\
\hline
\end{tabular}




\begin{tabular}{|c|c|}
\hline $\begin{array}{l}\text { domestic technology development, } \\
\text { research and innovation. }\end{array}$ & \\
\hline $\begin{array}{l}\text { 6. Ensure greater equity in international } \\
\text { trade by connecting the aims of those in } \\
\text { the Global North who seek greater } \\
\text { sustainability and justice with the needs } \\
\text { of those in the Global South who most } \\
\text { need those changes. }\end{array}$ & SDG 10:Reduced inequalities \\
\hline $\begin{array}{l}\text { 7. Support consumers make sustainable } \\
\text { choices and enhance producer's ability to } \\
\text { implement sustainable production } \\
\text { patterns. }\end{array}$ & $\begin{array}{l}\text { SDG 12: Responsible consumption and } \\
\text { production }\end{array}$ \\
\hline $\begin{array}{l}\text { 8. Encourage the responsible stewardship } \\
\text { of resources and environmentally } \\
\text { sustainable practices- reducing, reusing, } \\
\text { reclaiming, and recycling materials } \\
\text { wherever possible. }\end{array}$ & SDG 13: Climate change \\
\hline $\begin{array}{l}\text { 9. Make sure that everyone can develop } \\
\text { their full human potential. }\end{array}$ & SDG 16: peace and justice \\
\hline $\begin{array}{l}\text { 10. Create a platform with multiple partners } \\
\text { that supports governments to build } \\
\text { policies that can deliver on the ambitious } \\
\text { agenda laid out in the SDGs. }\end{array}$ & SDG17: partnerships for the Goals \\
\hline
\end{tabular}

Source: WFTO 2013

\section{Barriers to Fair Trade and Way Forward}

As a whole, FT movement support SDG by eliminating poverty; ending hunger; achieving gender equality; promoting decent work for all; ensuring sustainable consumption and production patterns; taking urgent action to combat climate change; promote peaceful and inclusive societies for SD, provide access to justice for all; strengthening the means of implementation and revitalize the global partnership for SD. A number of studies have also shown various positive impact of FT movement. A detailed study by Ronchi (2002), Jaffee (2007), Calo and Wise (2005)on Costa Rican and Mexico coffee co-operatives found that it has strengthened producer associations and established that FT in the early 1990s achieved its aim of developing the returns of small-scale producers in the light of the coffee crisis and positively affecting their standard of life in general. Other studies have emphasized that in a short period of time, FT initiatives have significantly improved the product quality of smallscale coffee farmers through training and improved skills, and the well-being of their families, especially with credit facilities and external funding (Murray et al. 2003). FT farmers were more successful in expanding their production, gaining better pricing experience for their crops, and seeing improved monthly household food intake and livelihoods, resulting in a significant reduction in infant mortality (Becchetti and Constantino 2008). Thus the overall concept of FT seems to have a very positive effect at first glance. Deeper digging below are some of the weaknesses of FT:

(i) Natural Limits to Success

FT organizations can produce lots of good for a society, but in the end their achievement is limited naturally to the center of local population where workers are located. This can cause diversity in a society because some workers may not fit in as part of the organization and may not get the amount of profits that coop workers are capable to achieve. 
(ii) Very High Membership Fees

To be indorsed for FT organization, an individual, or a cooperative has to be considered, and in this perspective, they must experience a period of expensive and difficult inspection. There is a joining fee which must be paid if recognized and an annual fee necessity to be paid in order to continue it. Even costs can run into the thousands of dollars, which can keep local businesspersons who are trying to adjust their communities out of reach of FT membership prices.

(iii) Limited Number of Customer

Because of high membership fees and cheapest wage rates for producers, compare to the "regular" products price, FT products obtain higher price that collapse the market of this type of product. Since for consumers whose income is low, the higher product price weight usually forces them to choose similar quality of low-cost product.

(iv) Reduced Choice of product

There are two main types of FT product those people generally purchase i.e., coffee and chocolate. Despite the numerous other products available for trade, these niche products do not have a very big market place. This indicates that there will be no demand for what is ultimately being created and it could disrupt the very existence of the job and even the cooperative as well.

(v) Higher Cost of Administration

The cost of FT is so high since that administrative costs are higher at the retail level. These extra costs aren't delivered along to the workers or the cooperatives and they attach with the local community and plug the financial bottom lines of businesses who are trading the FT products. This meant that exploitation on labor is still happening, but in a white collar way rather than a blue collar way.

(vi) Little Accountability

Although, efforts have been made to reduce worker abuse practices, but still child labor and slavery assist to fund FT products even after the certification deadline has been extended. There is no actual way to ensure that these annoying elements of business don't exists further since there is no reliable principal authority. It means that the only way to keep producers to be accountable is to backtrack on representing their goods.

(vii) Lack of Buyers attraction to fair trade

Most of the purchasers of FT products in the world are now looking at the total cost of purchasing their inventory. If assembly line production and factory farming can produce products of the same quality at 20-30\% lower prices, then the buyer will buy at lower prices. This makes it challenging for a FT sellers to get a real foot in the door and in the long run it damages environment because of implanting profitable practices rather than implementing sustainable practices.

(viii) Failed to Develop Standard Community

The FT model has not only been accused of handing over and altering the world economy, but some of the poorest producers and workers have had to pay the full value outside of the system. This implies that the FT movement can take some workers out of business so that it can support the situation, which is a paradox of why this movement was introduced at the outset.

(ix) No Drive to Create Better Efficiencies

If there is a certain minimum price, then there will be no inspiration for improving production efficiencies. In the end it means the purchaser is giving more for something without a reason. It means that the purchaser is repaying more to some degree without just reasons.

An underlying barrier to be overcome by implementing FT certified products which ought to be publicized. Target all the age group, and focus mostly on young customers with educational activities whose purchasing behavior is designed, not to be abandoned. According to the FT 
product purchasers, in most cases, polls should encourage people to buy products that are related to the FT concept, which is the best way to display FT products in stores as well as social promotion campaigns on the internet and in magazines. The strategic to achievement will also be acknowledged and recognize concerns, interests, and requirements of individual stakeholders and to build positions on issues thorough research based and then actively engage with individual groups (Charter 1992).

\section{Conclusion}

In conclusion, FT can make an authentic contribution to SD by reducing poverty and sustaining development in the developing nations. The FT movement together with the trade and development constituencies can support to ensure that this contribution is further going. So, at last it remarks us that FT mainly serves two objectives for the developing countries, namely: it offers real prospects for the improvement of small-scale workers and producers in developing nations; and it has had a positive impact on the worldwide trading system and private sectors, encouraging them to be more equitable, socially inclusive and supportive of SD.

\section{Synonyms}

Marginalized; Degradation; Disadvantaged; alleviating; mediators

\section{Cross References}

Trade as an Engine for reaching Sustainability

$>$ Trade with Less Developed Countries

\section{References}

Barratt Brown M (1993). Fair Trade. Zed Books, London.

Becchetti L, Constantino M (2008) 'The effects of fair trade on affiliated producers: an impact analysis on Kenyan farmers'.World Development 36 (5): 823-42.

Boto I, La Peccerella C (2008) Does fair trade contribute to sustainable development? Resources on fair trade, Brussels rural development briefings a series of meetings on ACP-EU development issues. https://brusselsbriefings. files.wordpress.com/2012/10/br5-reader-br-5-fair-tradeeng. Pdf.

Brussels Rural Development Briefings (2014) Does Fair Trade contribute to sustainable development? Available at: <https://brusselsbriefings.files.wordpress.com/ 2008/06/reader_fair_trade.pdf> [Accessed 3 March 2015].

Calo M, Wise TA (2005) Revaluing Peasant Coffee Production: Organic and Fair Trade Markets in Mexico, Global Development and Environment Institute, Medford MA: Tufts University.

Carroll AB (1991) The pyramid of corporate social responsibility: toward the moral management of organizational stakeholders. Buiness Horizons, 34.4, 39-48.

Charter (2009) A charter of fair trade principles. FLO, WFTO. https://www.wfto.com/sites/default/files/Charterof-Fair-Trade-Principles-Final\%20 (EN).PDF.

Charter M (1992) Greener Marketing. Greenleaf Publishing, Sheffield.

Cremona M, Durán GM (2012) 5 Fair trade in the European Union. The processes and practices of fair trade: trust, ethics and governance, p.122. 
De Pelsmacker P, Jamssens W, Mielants C (2005). Consumer Values and Fair -Trade Benefits, Attitudes and Buying Behaviour. International Review on Public and Non Profit Marketing, 2(2), pp.50-69.

FLO (2014) Fairtrade Standard for Hired Labour. Fairtrade International, 15.01.2014_v1.3. https://www.fairtrade.net/fileadmin/user_upload/content/2009/standards/doc uments/HL_EN.pdf.

FLO (2015a) Annual report 2014-2016, global change, local leadership. Fairtrade International. https:// annualreport14-15.fairtrade.net/en/.

Huybrechts B (2010). Explaining organisational diversity in fair trade social enterprises (Doctoral dissertation, HEC-Ecole de Gestion de l'Université de Liège, Liège, Belgique).

Jacobs M (1991) The Green Economy. Pluto Press, London.

Jaffee D (2007) Brewing Justice: Fair Trade Coffee, Sustainability and Survival, Berkeley, CA: University of California Press.

Ketola T (2009a) Five leaps to corporate sustainability through a corporate responsibility portfolio matrix. Corporate social responsibility and environmental management (published online)in Wiley interscience.

Latin America, Colorado State University: Fair Trade Research Group.

Murray DL, Raynolds, Taylor P (2003) One Cup at a Time: Poverty Alleviation and FT Coffee in

Pearcy DH, Schrock WA (2014) Fair Trade awareness: Exploring its relationship to public policy and sustainable outcomes. Research in Business and Economics Journal, [online] Available at: <http://www.aabri.com/manuscripts/141863.pdf> [Accessed 17 March 2015].

Reed D (2009). What do corporations have to do with fair trade? Positive and normative analysis from a value chain perspective. Journal of business ethics, 86(1), 3-26.

Renard MC (2003) 'Fair Trade: Quality, Market and Conventions'. Journal of Rural Studies 19, 87-96.

Ronchi L (2002) The Impact of Fair Trade on Producers and their Organizations: a Case Study with COOCAFE in Costa Rica, Poverty Research Unit Working Paper No 11, Brighton: University of Sussex.

Stefańska M, Nestorowicz R (2015). Development of Fair Trade Idea in Europe and the United States. In: M. Stefańska and R. Nestorowicz, eds. 2015. Fair Trade in CSR Strategy of Global Retailers. US: Palgrave Macmillan.

Strong C (1997) 'The Problem of Translating Fair Trade Principles into Consumer Purchase Behaviour'. Marketing Intelligence and Planning 15(1), 32-37.

United Nations (1987). Brundtland Report. Available at: <http://www. channelingreality.com/Documents/Brundtland_Searchable.pdf> [Accessed 3 March 2015].

Vieira LM, Aguiar LK (2009) An appraisal of the Fairtrade system evidence from small producers in emerging countries. In: A. Lindgreen, M.K. Hingley and J. Vanhamme, eds. 2009. The crisis of Food Brands: Sustaining Safe, Innovative and Competitive Food Supply. Farnham, Surrey: Gower.

WFTO (2008) Charter of fair trade principles. World Fair Trade Organization. https://wfto.com/fair-trade/charter-fairtrade-principles

WFTO (2013) 10 principles of fair trade. World Fair Trade Organization. https://www.wfto.com/sites/default/files/ 10-FAIR-TRADE-PRINCIPLES-2013-(RioAGM-and- EGM-2013-approved-modifications).pdf.

Young W, Uttin K (2005) Fair trade, business and sustainable development. Sustainable Development, 13(3), 139-142. 
